\title{
Pemodelan Jumlah Persediaan Suku Cadang Mesin ATM di Provinsi Jawa Timur dengan Regresi Spasial
}

\author{
Mohammad Naufal Abdullah, Rifda Zukhrufi Almas, Amelia Kurnia Salwa, Sutikno \\ Departemen Statistika, Fakultas Matematika Komputasi dan Sains Data \\ Institut Teknologi Sepuluh Nopember (ITS) \\ Jl. Arief Rahman Hakim, Surabaya 60111 Indonesia \\ e-mail :sutikno@statistika.its.ac.id
}

\begin{abstract}
Abstrak- Pelayanan ATM (Automated Teller Machine) adalah layanan perbankan yang dilakukan melalui mesin ATM yang dapat melayani selama 24 jam. Selain dapat membantu nasabah terkadang mesin ATM seringkali mengalami masalah kerusakan mesin. Pengalokasian persediaan suku cadang dari supplier ke gudang penyimpanan suku cadang (warehouse) yang berada di berbagai wilayah harus dilakukan dengan optimum dan efisien. Kasus ini mengandung informasi spasial, maka analisis data tidak akurat jika hanya menggunakan analisis regresi sederhana Penelitian ini akan membahas pemodelan jumlah persediaan suku cadang mesin ATM di Provinsi Jawa Timur. Sumber data pada penelitian ini adalah dari tugas akhir "Pemodelan Alokasi Persediaan Suku Cadang dengan Mempertimbangkan Pengaruh Spasial" oleh Siti Nur Afifah (1213100083). Metode yang akan digunakan adalah regresi spasial, karena diduga terdapat dependensi spasial pada variabelnya, sehingga dapat diketahui variabel prediktor yang berpengaruh signifikan terhadap jumlah persediaan suku cadang mesin ATM di Provinsi Jawa Timur. Berdasarkan analisis yang telah dilakukan, dapat diketahui bahwa jumlah persediaan suku cadang setiap kabupaten/kota di Jawa Timur berdistribusi normal dan terdapat dependensi spasial. Setelah dilakukan uji Lagrange Multiplier, dilanjutkan pemodelan menggunakan Spatial Lag Model (SLM) dan Spatial Error Model (SEM). Jumlah kerusakan suku cadang dan lifetime suku cadang berpengaruh signifikan terhadap jumlah persediaan suku cadang Provinsi Jawa Timur pada taraf signifikan 10\%. Harga suku cadang tidak memberikan pengaruh yang signifikan terhadap jumlah persediaan suku cadang. Spatial Error Model adalah model terbaik dalam pemodelan jumlah persediaan suku cadang mesin ATM di Provinsi Jawa Timur.
\end{abstract}

Kata Kunci-Dependensi Spasial, Jumlah Persediaan Suku Cadang, Regresi OLS, Spatial Error Model, Spatial Lag Model.

\section{PENDAHULUAN}

Pelayanan ATM (Automated Teller Machine) atau Anjungan Tunai Mandiri adalah layanan perbankan yang dilakukan melalui mesin ATM yang dapat melayani selama 24 jam, guna melakukan transaksi perbankan meliputi penarikan tunai, inquiry saldo (informasi saldo) rekening tabungan, setoran tunai dan melakukan berbagai jenis pembelian dan pembayaran tagihan. Selain dapat membantu nasabah terkadang mesin ATM seringkali mengalami masalah kerusakan mesin [1].

Permasalahan kerusakan mesin ATM merupakan tanggung jawab perusahaan penyedia jasa pemeliharaan mesin ATM. Setiap terjadi kerusakan membutuhkan suku cadang mesin untuk perbaikan, sedangkan suku cadang tidak selalu tersedia didalam gudang. Untuk itu pengalokasian persediaan suku cadang dari supplier ke gudang penyimpanan suku cadang (warehouse) yang berada di berbagai wilayah harus dilakukan dengan optimum dan efisien.

Alokasi jumlah persediaan dapat dipengaruhi oleh beberapa faktor, dan juga dipengaruhi oleh wilayah di sekitarnya. Untuk menentukan pengalokasian persediaan suku cadang diperlukan suatu model yang menjelaskan hubungan antara jumlah persediaan dan faktor-faktor yang mempengaruhi dan juga faktor spasial atau wilayah. Kasus ini mengandung informasi spasial, maka analisis data tidak akurat jika hanya menggunakan analisis regresi sederhana [2]

Penelitian ini akan membahas tentang pemodelan jumlah persediaan suku cadang mesin ATM di Provinsi Jawa Timur dengan 3 variabel prediktor dan 1 variabel respon. Adanya hubungan spasial dalam variabel respon menyebabkan pendugaan menjadi tidak tepat karena asumsi keacakan suatu error dilanggar. Untuk mengatasi permasalahan tersebut diperlukan suatu model regresi yang memasukkan hubungan spasial antar wilayah ke dalam model. Metode yang akan digunakan adalah OLS (Ordinary Least Square) dan dilanjut dengan pemilihan model regresi spasial dengan melakukan uji Lagrange Multiplier. Pemodelan dengan pendekatan spasial menggunakan Spatial Lag Model (SLM) dan Spatial Error Model (SEM). Penelitian ini diharapkan dapat menjadi informasi bagi perusahaan penyediaan jasa pemeliharaan mesin ATM untuk alokasi persediaan suku cadang.

\section{METODOLOGI PENELITIAN}

\section{A. Sumber Data}

Data yang digunakan dalam penelitian ini data sekunder yang diperoleh dari data penelitian tugas akhir "Pemodelan Alokasi Persediaan Suku Cadang dengan Mempertimbangkan Pengaruh Spasial" oleh Siti Nur Afifah (1213100083). Variabel yang digunakan adalah sebagai berikut.

\begin{tabular}{cl} 
& \multicolumn{1}{c}{ Tabel 1. Variabel Penelitian } \\
\hline Variabel & \multicolumn{1}{c}{ Keterangan } \\
\hline $\mathrm{Y}$ & $\begin{array}{l}\text { Jumlah Persediaan Suku Cadang } \\
\text { Jumlah Kerusakan Suku Cadang } \\
\text { terhadap 1000 kali Transaksi }\end{array}$ \\
$\mathrm{X}_{1}$ & $\begin{array}{l}\text { Harga Suku Cadang terhadap Total } \\
\text { Budget } \\
\mathrm{X}_{2}\end{array}$ \\
$\mathrm{X}_{3}$ & $\begin{array}{l}\text { Lifetime Suku Cadang terhadap 1000 } \\
\text { kali Transaksi }\end{array}$ \\
\hline
\end{tabular}

B. Struktur Data

Struktur data dari penelitian ini adalah sebagai berikut. 
Tabel 2. Struktur Data Penelitian

\begin{tabular}{ccccc}
\hline Kecamatan & $\boldsymbol{Y}$ & $\boldsymbol{X}_{\boldsymbol{1}}$ & $\boldsymbol{X}_{\mathbf{2}}$ & $\boldsymbol{X}_{\mathbf{3}}$ \\
\hline 1 & $Y_{1}$ & $X_{1,1}$ & $X_{2,1}$ & $X_{3,1}$ \\
2 & $Y_{2}$ & $X_{1,2}$ & $X_{2,2}$ & $X_{3,2}$ \\
$\ldots$ & $\ldots$ & $\ldots$ & $\ldots$ & $\ldots$ \\
38 & $Y_{18}$ & $X_{1,38}$ & $X_{2,38}$ & $X_{3,38}$ \\
\hline
\end{tabular}

\section{Langkah Analisis}

Langkah analisis yang digunakan pada penelitian ini adalah sebagai berikut.

1. Mengidentifikasi masalah dan mengumpulkan data.

2. Melakukan analisis karakteristik data menggunakan peta tematik dan pola hubungan antar variabel.

3. Menentukan matriks pembobot rook contiguty.

4. Melakukan uji dependensi spasial dengan uji Moran's I.

5. Melakukan pemodelan dengan regresi OLS.

6. Melakukan uji Lagrange Multiplier.

7. Melakukan pemodelan regresi spasial.

8. Melakukan pemilihan model terbaik.

9. Menginterpretasikan model.

10. Menarik kesimpulan dan saran.

\section{Metode Analisis}

Metode yang digunakan adalah regresi linier berganda OLS (Ordinary Least Square) dan model regresi spasial.

Analisis regresi linier berganda merupakan persamaan matematik yang menjelaskan hubungan variabel respon $(Y)$ dengan variabel prediktor $\left(X_{1}, X_{2}, \ldots, X_{k}\right)$ dimana variabel prediktor yang mempengaruhinya lebih dari satu jumlahnya [3]. Model regresi linier berganda dengan $k$ variabel prediktor dalam bentuk matriks dapat dituliskan sebagai berikut.

$$
Y=X \beta+\varepsilon
$$

Pemodelan spasial sangat erat dengan proses autoregressive ditunjukkan dengan adanya hubungan ketergantungan antar sekumpulan pengamatan atau lokasi [4] Model Spatial Autoregressive merupakan model yang mengkombinasikan model regresi sederhana dengan lag spasial pada variabel dependen menggunakan data cross section [5]. Model ini terbentuk apabila $\rho \neq 0$ dan $\lambda=0$.

$$
Y=\rho W Y+X \beta+\varepsilon
$$

Model spasial error ditemukan error pada korelasi spasialnya. Model spasial error ini terbentuk apabila $\rho=0$ dan $\lambda \neq 0$ sehingga model ini kemudian mengasumsikan bahwa proses autoregressive hanya pada error model saja [5]

$$
Y=X \beta+\lambda W U+\varepsilon
$$

$\rho$ adalah parameter koefisien spasial lag variabel dependen, $\lambda$ adalah parameter koefisien spasial lag pada eror, $W$ adalah matrik pembobot untuk pengaruh spasial antar lokasi dalam model (I).

Pengujian lagrange multiplier digunakan sebagai dasar untuk memilih model regresi spasial yang sesuai. LM error signifikan maka model yang sesuai adalah SEM dan apabila LM lag signifikan maka model yang sesuai adalah SAR atau SLM. Hipotesis yang digunakan pada LM lag adalah,

$\mathrm{H}_{0}: \rho=0$ (tidak ada dependensi spasial lag)

$\mathrm{H}_{1}: \rho \neq 0$ (ada dependensi spasial lag)

Hipotesis yang digunakan pada LM error adalah

$\mathrm{H}_{0}: \lambda=0$ (tidak ada dependensi spasial error)

$\mathrm{H}_{1}: \lambda \neq 0$ (ada dependensi spasial error)

$\mathrm{LM}$ lag dan LM error tolak $\mathrm{H}_{0}$, jika $\mathrm{P}-$ Value $<\alpha$.
Efek dependensi spasial membuat nilai autokorelasi spasial menjadi positif terhadap residual. Efek dependensi spasial dilakukan menggunakan pengujian Moran's I. Hipotesis yang digunakan adalah,

$\mathrm{H}_{0}: I=0$ (tidak ada autokorelasi antar lokasi)

$\mathrm{H}_{1}: I \neq 0$ (ada autokorelasi antar lokasi)

Statistik Uji :

$$
Z=\frac{I-E(I)}{\sqrt{\operatorname{Var}(I)}}
$$

\section{ANALISIS DAN PEMBAHASAN}

\section{A. Statistika Deskriptif}

Analisis statistika deskriptif dilakukan untuk mengetahui sifat atau karakter dari suatu data sebelum dilakukan analisis pemodelan lebih lanjut. Statistika deskriptif untuk setiap variabel adalah sebagai berikut.

Tabel 3. Statistika deskriptif

\begin{tabular}{ccccc}
\hline Variabel & Rata-rata & $\begin{array}{c}\text { Standar } \\
\text { Deviasi }\end{array}$ & Minimum & Maksimum \\
\hline$Y$ & 5,658 & 2,464 & 1,000 & 10,000 \\
$X_{1}$ & 5,711 & 2,437 & 1,000 & 10,000 \\
$X_{2}$ & 4,026 & 2,224 & 1,000 & 10,000 \\
$X_{3}$ & 4,947 & 2,731 & 1,000 & 10,000 \\
\hline
\end{tabular}

Rata-rata jumlah persediaan suku cadang adalah sebanayak 5,658 unit. Artinya setiap 1 kabupaten/kota ratarata memiliki jumlah persediaan suku cadangan sekitar 5 sampai 6 unit. Begitu pula dengan jumlah kerusakan suku cadang terhadap 100 kali transaksi memiliki rata-rata sebesar 5,711 unit. Artinya untuk setiap 1 kabupaten/kota rata-rata memiliki 5 sampai 6 kerusakan suku cadang setiap 1000 kali transaksi. Setiap 1 kabupaten/kota rata-rata memiliki sekitar 4 satuan untuk harga suku cadang terhadap total budget dan sekitar 4 sampai 5 satuan untuk lifetime suku cadang terhadap 1000 kali transaksi.

Analisis statistika deskriptif untuk setiap variabel di Provinsi Jawa Timur dapat divisualisasikan dengan peta tematik. Berikut merupakan statistika deskriptif dari peta sebaran jumlah persediaan suku cadang tiap kabupaten/kota di Provinsi Jawa Timur.

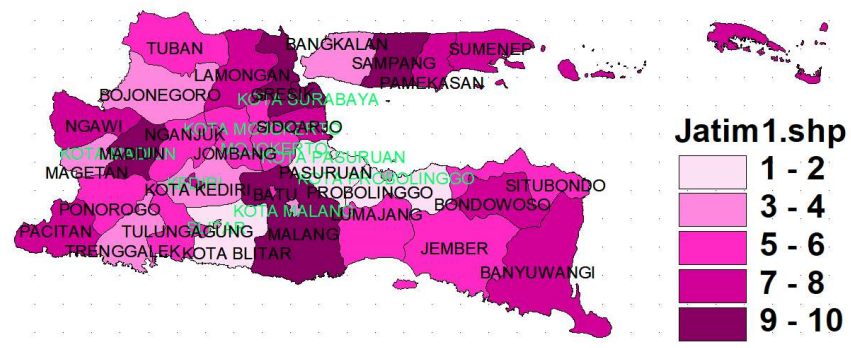

Gambar 1. Peta Sebaran Jumlah Persediaan Suku Cadang di Provinsi Jawa Timur

Berdasarkan Gambar 1, informasi yang didapatkan adalah terdapat tiga kabupaten/kota dengan jumlah persediaan suku cadang terendah yakni Kabupaten Blitar, Pasuruan, dan Probolinggo masing-masing 1 persediaan, 1 persediaan, dan 2 persediaan. Daerah dengan jumlah persediaan suku cadang kategori tinggi adalah Kabupaten Madiun, Gresik, Surabaya, Malang, dan Sampang sekitar 9 sampai 10 persediaan suku cadang. Gambar 1 juga menunjukkan bahwa secara visual terdapat beberapa kabupaten/kota yang saling berdekatan memiliki karakteristik yang hampir sama, sehingga diduga terdapat efek spasial (keterkaitan lokasi yang berdekatan) pada jumlah persediaan suku cadang di Provinsi Jawa Timur. 
Kabupaten Blitar, Trenggalek, Kota Madiun, Bojonegoro, dan Bangkalan mempunyai jumlah persediaan suku cadang yang kecil namun dikelilingi oleh daerah dengan jumlah persediaan suku cadang lebih banyak. Kabupaten Madiun, Malang, dan Sampang memiliki jumlah persediaan suku cadang yang besar, namun dikelilingi kabupaten/kota dengan jumlah suku cadang yang lebih kecil.

Berikut merupakan peta sebaran jumlah kerusakan suku cadang terhadap 1000 kali transaksi tiap kabupaten/kota di Provinsi Jawa Timur.
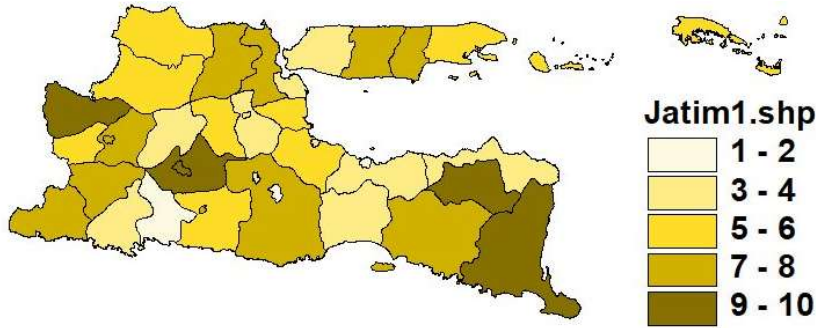

Gambar 2. Peta Sebaran Jumlah Kerusakan Suku Cadang Terhadap 1000 Kali Transaksi di Provinsi Jawa Timur

Berdasarkan Gambar 2, informasi yang didapatkan adalah terdapat tiga kabupaten/kota dengan jumlah kerusakan suku cadang terhadap 1000 kali transaksi yakni Kabupaten Tulungagung, Kota Malang, dan Probolinggo masing-masing 1 kerusakan, 2 kerusakan, dan 2 kerusakan. Daerah dengan jumlah kerusakan suku cadang terhadap 1000 kali transaksi kategori tinggi adalah Kota Kediri, Kabupaten Banyuwangi, Ngawi, Bondowoso, dan Kediri sekitar 9 sampai 10 kerusaka suku cadang setiap 1000 kali transaksi.

Berikut merupakan peta sebaran harga suku cadang terhadap total budget tiap kabupaten/kota di Provinsi Jawa Timur.

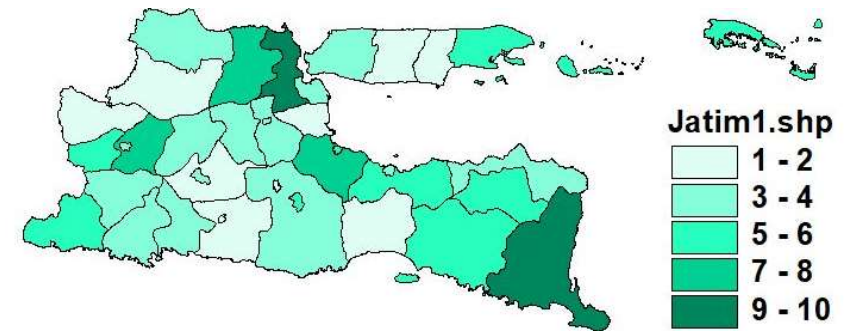

Gambar 3. Peta Sebaran Harga Suku Cadang Terhadap Total Budget di Provinsi Jawa Timur

Berdasarkan Gambar 3, informasi yang didapatkan adalah terdapat sembilan kabupaten/kota dengan harga suku cadang terhadap total budget yakni Kabupaten Sampang, Pamekasan, Bojonegoro, Blitar, Kota Blitar, Kota Kediri, Kota Batu, Kabupaten Lumayang, Ngawi, dan Sidoarjo yang memiliki harga suku cadang terhadap total budget sebesar sekitar 1 sampai 2 satuan. Daerah dengan harga suku cadang terhadap total budget kategori tinggi adalah Kabupaten Banyuwangi dan Gresik yaitu dengan harga suku cadang terhadap total budget sebesar 9 sampai 10 satuan.

Berikut merupakan peta sebaran lifetime suku cadang terhadap 1000 kali transaksi tiap kabupaten/kota di Provinsi Jawa Timur.

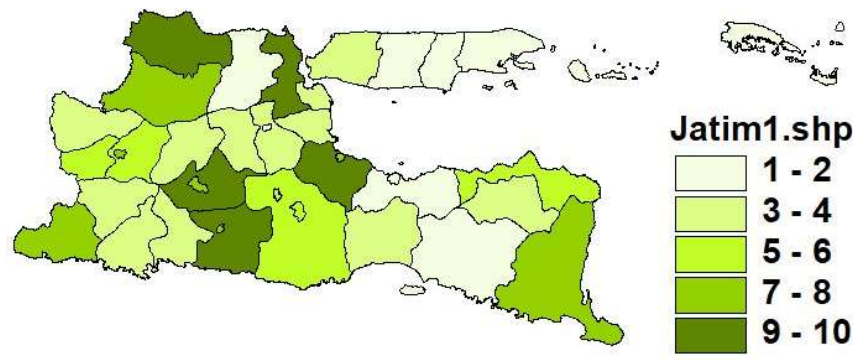

Gambar 4. Peta Sebaran Lifetime Suku Cadang Terhadap 1000 Kali Transaksi di Provinsi Jawa Timur

Berdasarkan Gambar 4, informasi yang didapatkan adalah terdapat delapan kabupaten/kota dengan lifetime suku cadang terhadap 1000 kali transaksi yakni Kabupaten Sumenep, Sampang, Pamekasan, Lamongan, Jember, Probolinggo, Kota Mojokerto, dan Kota Probolinggo yang memiliki lifetime suku cadang terhadap 1000 kali transaksi sekitar 1 sampai 2 satuan. Daerah dengan lifetime suku cadang terhadap 1000 kali transaksi kategori tinggi adalah Kabupaten Gresik, Pasuruan, Kota Kediri, Kabupaten Tuban, dan Kota Blitar sekitar 9 sampai 10 satuan untuk lifetime suku cadang terhadap 1000 kali transaksi.

Selain disajikan peta tematik jumlah persediaan suku cadang di Jawa Timur, disajikan pula hubungan antar variabel sebagai berikut.

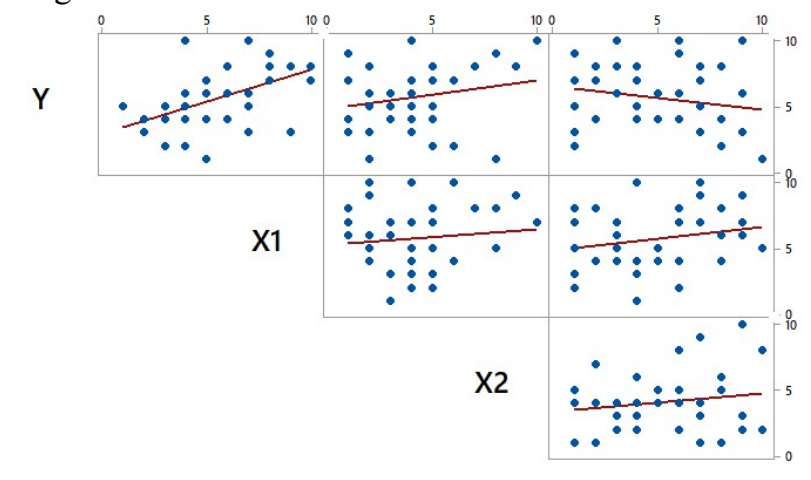

X3

Gambar 5. Pola Hubungan Antar Variabel

Pada Gambar 5, diperoleh informasi bahwa pola hubungan antara jumlah persediaan suku cadang dengan jumlah kerusakan suku cadang $\left(\mathrm{X}_{1}\right)$ dan harga suku cadang $\left(\mathrm{X}_{2}\right)$ adalah hubungan yang positif, dimana semakin tinggi jumlah kerusakan suku cadang atau harga suku cadang, maka jumlah persediaan juga semakin tinggi. Hubungan antara jumlah persediaan dan lifetime suku cadang $\left(\mathrm{X}_{3}\right)$ saling berlawanan atau negatif, sehingga semakin tinggi lifetime suku cadang, maka jumlah persediaan suku cadang semakin rendah. Hubungan antara jumlah persediaan suku cadang dengan jumlah kerusakan suku cadang cukup kuat jika dibandingkan dengan harga dan lifetime suku cadang. Berdasarkan Gambar 2 diduga tidak terdapat multikolinieritas antar variabel prediktor.

\section{B. Uji Distribusi Variabel Respon}

Uji distribusi pada variabel respon dilakukan untuk mengetahui apakah distribusi dari jumlah persediaan suku cadang mengikuti distribusi normal atau tidak. Pada pengujian distribusi pada jumlah persediaan suku cadang Provinsi Jawa Timur akan menggunakan uji KolmogorovSmirnov. Hasil pengujian Kolmogorov-Smirnov jumlah persediaan suku cadang Provinsi Jawa Timur dengan taraf signifikan $10 \%$ disajikan sebagai berikut.

Tabel 4. Uji Distribusi dengan Kolmogorov-Smirnov

\begin{tabular}{ccc}
\hline KS & P-Value & Keputusan \\
\hline 0.10529 & 0.754 & Gagal Tolak $\mathrm{H}_{0}$ \\
\hline Ber
\end{tabular}

Berdasarkan hasil uji distribusi menggunakan uji Kolmogorov-Smirnov maka didapatkan keputusan gagal tolak $\mathrm{H}_{0}$, sehingga data jumlah persediaan suku cadang tiap kabupaten/kota di Provinsi Jawa Timur berdistribusi normal.

\section{Uji Dependensi Spasial}

Uji dependensi spasial dilakukan untuk mengetahui adanya keterkaitan karateristik lokasi yang berdekatan. Pada 
pengujian dependensi spasial pada jumlah persediaan suku cadang Provinsi Jawa Timur akan menggunakan uji Moran's I. Berikut merupakan hasil pengujian Moran's I jumlah persediaan suku cadang Provinsi Jawa Timur dengan taraf signifikan $10 \%$.

Tabel 5. Uji Dependensi Spasial dengan Moran's I

\begin{tabular}{ccc}
\hline Moran's I & P-Value & Keputusan \\
\hline 0.200737 & 0.041 & Tolak $\mathrm{H}_{0}$ \\
\hline
\end{tabular}

Berdasarkan hasil uji dependensi menggunakan uji Moran's I maka didapatkan keputusan tolak $\mathrm{H}_{0}$, sehingga kesimpulan yang dapat diambil adalah bahwa terdapat dependensi spasial pada jumlah persediaan suku cadang Provinsi Jawa Timur. Nilai Moran's I positif, sehingga antar kabupaten/kota yang saling berdekatan memiliki jumlah persediaan suku cadang yang relatif sama (karakteristik mirip).

\section{Pemodelan Regresi OLS}

Langkah selanjutnya adalah melakukan pemodelan menggunakan regresi linear OLS (Ordinary Least Square). Berikut merupakan hasil estimasi dan uji signifikansi parameter dengan menggunakan metode OLS dengan melibatkan variabel yang signifikan menggunakan taraf signifikan $10 \%$.

Tabel 6. Estimasi dan Uji Parameter Model OLS

\begin{tabular}{ccc}
\multicolumn{3}{c}{ Tabel 6. Estimasi dan Uji Parameter Model OLS } \\
\hline Variabel & Estimasi & P-Value \\
\hline Intercept & 3.915887 & $0.0004^{*}$ \\
$\mathrm{X}_{1}$ & 0.545767 & $0.0006^{*}$ \\
$\mathrm{X}_{3}$ & -0.277847 & $0.0374^{*}$ \\
\hline
\end{tabular}

Keterangan : $\quad *$ Signifikan pada taraf $10 \%$

Tabel 6 menjelaskan bahwa jumlah kerusakan suku cadang dan lifetime suku cadang berpengaruh terhadap jumlah persediaan suku cadang pada taraf signifikan $10 \%$. Harga suku cadang tidak memberikan pengaruh yang signifikan terhadap jumlah persediaan suku cadang. Model OLS jumlah persediaan suku cadang di Provinsi Jawa Timur dapat dituliskan sebagai berikut.

$$
\hat{Y}_{i}=3.915887+0.545767 X_{1 i}-0.277847 X_{3 i}
$$

\section{E. Uji Lagrange Multiplier}

Setelah diperoleh model regresi OLS, maka akan dilakukan uji Lagrange Multiplier untuk mendeteksi dependensi spasial atau model spasial. Terdapat 3 pengujian, diantaranya adalah uji Robust LM Lag untuk mendeteksi dependensi spasial berdasarkan Lag, uji Robust LM Error untuk dependensi spasial berdasarkan residual dan uji $L M$ Sarma untuk dependensi spasial campuran (lag dan residual). Pengujian dari Lagrange Multiplier dengan taraf signifikan sebesar $10 \%$ disajikan sebagai berikut.

\begin{tabular}{ccc} 
& Tabel 7. Uji Lagrange Multiplier \\
\hline Uji & P-Value & Keputusan \\
\hline LM Lag & 0.0318 & Tolak $\mathrm{H}_{0}$ \\
Robust LM Lag & 0.4288 & Gagal Tolak $\mathrm{H}_{0}$ \\
LM Error & 0.0447 & Tolak $\mathrm{H}_{0}$ \\
Robust LM Error & 0.8278 & Gagal Tolak $\mathrm{H}_{0}$ \\
LM Sarma & 0.0976 & Tolak $\mathrm{H}_{0}$ \\
\hline
\end{tabular}

Berdasarkan Tabel 7, diketahui jika nilai P-Value dari $L M$ Lag, LM Error, dan LM Sarma lebih kecil dari taraf signifikan $10 \%$, sedangkan nilai P-Value dari Robust LM Lag dan Robust LM Error lebih besar dari taraf signifikan. Sesuai dengan hasil uji $L M$ diindikasikan adanya dependensi spasial berdasarkan Lag atau Error. Tahap selanjutnya akan dilakukan pemodelan menggunakan Spatial Lag Model (SLM) atau Spatial Autoregressive (SAR) dan Spatial Error Model (SEM).

\section{F. Pemodelan Spatial Lag Model}

Berikut merupakan estimasi dan uji signifikansi parameter Spatial Lag Model (SLM) menggunakan MLE.

Tabel 8. Estimasi dan Uji Parameter Spatial Lag Model

\begin{tabular}{ccc}
\hline Variabel & Estimasi & P-Value \\
\hline $\mathrm{W}$ & 0.248111 & $0.0993^{*}$ \\
Intercept & 2.365054 & $0.0614^{*}$ \\
$\mathrm{X}_{1}$ & 0.563046 & $0.0000^{*}$ \\
$\mathrm{X}_{3}$ & -0.275893 & $0.0189^{*}$ \\
\hline
\end{tabular}

Keterangan : $\quad *$ Signifikan pada taraf $10 \%$

Pada Tabel 8 dapat ditunjukkan bahwa terdapat dependensi spasial pada jumlah persediaan suku cadang tiap kabupaten/kota pada taraf signifikan 10\%. Jumlah kerusakan suku cadang dan lifetime suku cadang berpengaruh signifikan terhadap jumlah persediaan suku cadang Provinsi Jawa Timur pada taraf signifikan 10\%. Berikut dituliskan model spasial lag (spatial lag model) jumlah persediaan suku cadang Provinsi Jawa Timur.

$$
\begin{aligned}
\hat{Y}_{i}= & 2.365054+0.248111 \sum_{j=1, i \neq j}^{38} W_{i j} Y_{j}+0.563046 X_{1 i} \\
& -0.275893 X_{3 i}
\end{aligned}
$$

\section{G. Pemodelan Spatial Error Model}

Hasil estimasi dan uji signifikansi parameter Spatial Error Model (SEM) menggunakan MLE.

Tabel 9. Estimasi dan Uji Parameter Spatial Error Model

Intercept

Estimasi
P-Value

$\mathrm{X}$ 3.872937 $0.0000^{*}$ $\mathrm{X}_{3}$ 0.561639 $0.0000^{*}$

$\begin{array}{lll}\mathrm{X}_{3} & -0.285469 & 0.0206^{*}\end{array}$

$\mathrm{W}$ 0.283498 $0.0945^{*}$

Keterangan : $\quad$ * Signifikan pada taraf $10 \%$

Tabel 9 menunjukkan bahwa terdapat dependensi spasial pada residual jumlah persediaan suku cadang tiap kabupaten/kota pada taraf signifikan 10\%. Jumlah kerusakan suku cadang dan lifetime suku cadang berpengaruh signifikan terhadap jumlah persediaan suku cadang Provinsi Jawa Timur pada taraf signifikan 10\%. Berikut dituliskan model spasial error (spatial error model) jumlah persediaan suku cadang Provinsi Jawa Timur.

$$
\begin{aligned}
\hat{Y}_{i}= & 3.872937+0.561639 X_{1 i}-0.285469 X_{3 i} \\
& +0.283498 \sum_{j=1, i \neq j}^{38} W_{i j} U_{j}
\end{aligned}
$$

\section{H. Perbandingan Model antara Regresi OLS dengan Spatial Model}

Perbandingan model merupakan suatu prosedur untuk memilih model terbaik dengan membandingkan ukuranukuran kebaikan model. Ukuran kebaikan model yang digunakan untuk membandingkan model regresi OLS dan spatial lag model adalah nilai AIC.

\begin{tabular}{cc|}
\multicolumn{2}{c}{ Tabel 10. Perbandingan Model Terbaik } \\
\hline Model & AIC \\
\hline Spatial Lag Model & 165.335 \\
Spatial Error Model & 163.510 \\
Regresi OLS & 166.710 \\
\hline
\end{tabular}

Berdasarkan Tabel 10 diperoleh model terbaik yang terpilih adalah model Spatial Error (Spatial Error Model), karena memiliki nilai AIC yang lebih kecil daripada AIC model Spasial Lag dan Regresi Linear OLS. Sehingga dapat dikatakan bahwa spatial error model merupakan model 
terbaik dalam pemodelan jumlah persediaan suku cadang Provinsi Jawa Timur.

\section{Interpertasi Model Spatial Error Model}

Model yang terpilih adalah model spasial error (Spatial Error Model) dan tiap kabupaten/kota di Jawa Timur memiliki bentuk spatial error model yang berbeda-beda dipengaruhi oleh pembobot kedekatan antara kabupaten/kota satu dengan kabupaten/kota lainnya. Berikut diajikan spatial error model Kota Surabaya.

$$
\begin{aligned}
\hat{Y}_{\text {Surabaya }}= & 3.872937+0.561639 X_{1 \text { Surabaya }} \\
& -0.285469 X_{3 \text { Surabaya }} \\
& +0.141749\left(U_{\text {Gresik }}+U_{\text {Sioarjo }}\right)
\end{aligned}
$$

Peningkatan 2 buah jumlah kerusakan suku cadang di Surabaya, maka jumlah persediaan suku cadang di Surabaya akan bertambah sebesar 1.123278 atau 1 buah dengan catatan variabel prediktor lain konstan. Lifetime suatu suku cadang di Surabaya bertambah 5 satuan, maka jumlah persediaan suku cadang di Surabaya akan berkurang sebesar 1.427345 atau 12 buah. Nilai error dari Gresik dan Sidoarjo memberikan pengaruh terhadap spatial error model jumlah persediaan suku cadang di Surabaya sebesar 0.141749.

\section{KESIMPULAN DAN SARAN}

\section{A. Kesimpulan}

Berdasarkan analisis yang telah dilakukan dapat diketahui bahwa data jumlah persediaan suku cadang di Provinsi Jawa Timur berdistribusi normal dan terdapat dependensi spasial pada jumlah persediaan suku cadang di Provinsi Jawa Timur. Setelah dilakukan uji Lagrange Multiplier, dilanjutkan pemodelan menggunakan Spatial Lag Model (SLM) dan Spatial Error Model (SEM). Jumlah kerusakan suku cadang dan lifetime suku cadang berpengaruh signifikan terhadap jumlah persediaan suku cadang Provinsi Jawa Timur pada taraf signifikan $10 \%$. Harga suku cadang tidak memberikan pengaruh yang signifikan terhadap jumlah persediaan suku cadang. Spatial Error Model adalah model terbaik dalam pemodelan jumlah persediaan suku cadang di Provinsi Jawa Timur dan dapat dituliskan sebagai berikut.

$$
\begin{aligned}
\hat{Y}_{i}= & 3.872937+0.561639 X_{1 i}-0.285469 X_{3 i} \\
& +0.283498 \sum_{j=1, i \neq j}^{38} W_{i j} U_{j}
\end{aligned}
$$

\section{B. Saran}

Saran yang dapat diberikan pada penelitian ini yaitu memperdalam studi literatur sebagi pendukung untuk pemilihan variabel yang digunakan dalam pemodelan dan mempertahankan ketelitian agar meminimalisir kesalahan saat pengerjaan. Saran dan informasi tambahan untuk instansi penyediaan jasa dan pemeliharaan ATM untuk mempertimbangkan faktor-faktor seperti kerusakan dan lifetime suku cadang mesin ATM, serta wilayah kabupaten/kota di Jawa Timur dalam menentukan jumlah persediaan suku cadang mesin ATM yang tepat dan sesuai kebutuhan.

\section{DAFTAR PUSTAKA}

[1] B.A. Yuwono, “Analisa Dari Desain Dan Permasalahan pada Mesin Atm di Bank Mega", Jakarta, Universitas Gunadarma, 2007.

[2] L. Anselin, "Spatial Econometrics : Methods and Models", Netherlands, Kluwer Academic Publishers, 1988.

[3] B. Sumantri, "Analisis Regresi Terapan Edisi Kedua," in Applied Regression Analysis (Second Edition), Jakarta, PT Gramedia Pustaka Utama, 1992, p. 688

[4] M. D. Ward and K. S. Gleditsch, Spatial Regression Model, California: Sage Publications, Inc, 2008.

[5] J. P. LeSage, The Theory and Practice of Spatial Econometrics, Asia Pacific Press, 1999 